\title{
Teaching With Data In The Principles Of Macroeconomics Course
}

\author{
Hong Zhuang, Indiana University South Bend, USA
}

\begin{abstract}
Economic data play an important role in the study of macroeconomics. Teaching with data through interactive classes can engage students more fully in the learning process. Although the pedagogy of teaching with data has been widely applied in the undergraduate science classroom, its extension to the economics classroom is rarely discussed. This paper attempts to fill in this paucity in the literature by discussing two examples of integrating economic data in a principles of macroeconomics course.
\end{abstract}

Keywords: Principles of Macroeconomics; Data; Interactive Lectures

\section{INTRODUCTION}

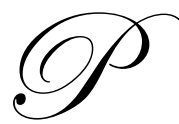

rinciples of Macroeconomics is an introductory level course that exposes students to the foundation and tools of the discipline of economics and examines the economy as a whole. Economic data are important to the study of macroeconomics because the data reveal a true picture of the state of the economy. Hence, economic data allow one to understand how an economy measures up with respect to other economies and whether the economy has functioned properly. Such data can help one determine whether fiscal and monetary policies have been fruitful or not. Put differently, "accurate measures of the macroeconomic variables (aggregate output, inflation, unemployment) are critical for understanding the economy. Without good measures, economists would have a hard time analyzing how the economy works and policy makers would have little to guide them on which policies are best for the economy." (Case, Fair and Oster, 2010).

College students typically enroll in a principles-of-macroeconomics course because it is required of business majors, because it fulfills a breadth requirement, or because of general interest the class is to the students (Kennedy, 2006). Given that a macroeconomic principles course may represent the only chance to teach students something about the macroeconomy, economists often differ on the content of this course. This study agrees with Boskin (1998) that, ideally, such a class will "help my students to achieve mastery of enough simple analysis and descriptive overview that they can read the newspaper intelligently and critically. Hopefully they enjoy the process enough so that they will - or at least a substantial fraction of them will - keep up their interest in economics and economic events."

In meeting these goals, macroeconomics textbooks become an important resource for providing a ready reference for students beyond daily lectures. Many principles textbooks are comprehensive, covering principles, news, exercises, etc. Yet, keeping a textbook current by topics and useful information is a major problem with textbooks (Boskin, 1998). For example, the latest edition of Principles of Macroeconomics by Case, Fair and Oster relies primarily on 2009 data. However, the U.S. economy has undergone major upheavals since that time. Therefore, it is critical for the instructor to provide updated information from statistical bureaus and newspapers in order to present the most recent picture of the economy to students. Furthermore, the figures in the textbook often describe the national economy; whereas students may be more interested in understanding the local economy. Accordingly, the selection of statistical data reflecting local issues would better serve students' needs. Lastly, the mere presentation of textbook figures in a Power-Point format relies on passive learning techniques rather than involving the students actively in the learning process. 
Likewise, lecturing, though a time-honored, extensively used, and efficient teaching technique for presenting large amounts of information, may result in students merely listening passively. On the other hand, interactive classes that include activities that break the lecture into short segments may lead to better educational outcomes. Indeed, Wenzel (1999) reports that in large science classes, 92 percent of the time is spent on lecture, 4 percent on student questions, and 4 percent in silence. Wenzel (1999) further suggests that, during a lecture, students are attentive only $50-60$ percent of the time. Based on students' self-reporting and observations, Wenzel (1999) shows that students record less material progressively in a predominantly lecture format: for example, 40 percent of the lecture material in a 15-minute lecture, 25 percent in a 30-minute lecture, and 20 percent in a 40 -minute lecture. Moreover, Wenzel's investigation indicates that a class that uses a think-pair-share technique for two to three minutes for every $12-18$ minutes of lecture increases student recall of the lecture material for twelve days longer than the control class that does not utilize this technique. Similarly, Hake's (1998) survey of pre- and post- test results for over 6000 students in physics courses from high schools, colleges, and universities concludes that interactive-engagement methods enhance problem-solving abilities and increase course effectiveness well beyond those that eschew interactive-engagement methods.

Teaching with data in properly designed classroom activities is a form of interactive classes. This pedagogical approach can encourage positive student attitudes toward reading, improve math skills, motivate students to talk with their peers and parents about what they read, and help students learn how to solve real world economic issues. Designing data-oriented classroom activities based on such salutary pedagogical foundations and extending them to economics courses thus seem warranted. Useful analogies can be derived from the literature relating to undergraduate science programs, where teaching with data enjoys a rich history. The report on Using Data in the Undergraduate Science Classrooms identifies several reasons for engaging students with data as part of scientific training: preparing students to address real-world complex problems, developing students' ability to use scientific methods, preparing students to critically evaluate the interpretations or conclusions of data, teaching quantitative skills, increasing verbal, written and graphical communication skills, motivating learning through student interest in a particular problem, and providing students an excellent interactive engagement environment with heads-on and hands-on opportunities. ${ }^{1}$ However, teaching with data is rarely discussed and stressed in economics pedagogical research. Therefore, Section II of this paper intends to fill in the paucity in this literature by presenting two examples of teaching with data, which applications interactively engage students in the learning process. Section III presents conclusions and recommendations for further research.

\section{APPLICATIONS OF TEACHING WITH DATA IN ECONOMICS}

The class activities in which students collect and interpret data are designed to bridge the gap between classroom learning and real-world living; to help foster global awareness and understanding of local issues; to create informed citizens; to offer examples of conflict and resolution; and to develop reading, thinking and writing skills.

\section{Case 1: Gross Domestic Product (GDP)}

GDP is usually the first topic taught in principles of macroeconomics courses. The concept of GDP has broad implications, including approaches to calculate GDP, nominal and real GDP, and indications of economic expansion and recession. Simply presenting static information does not help students understand the repercussions of GDP in the national economy. The same is true of textbooks: even though they provide figures on GDP from the Bureau of Economic Analysis, such figures often are a mere snapshot of national economy at a certain point of time, instead of a dynamic picture of the national economy over a period of time. For example, the latest edition of Principles of Macroeconomics by Case, Fair and Oster (2010) presents a table on the U.S. nominal GDP using the expenditure approach for the year 2009. However, annual GDP figures do not provide sufficient detail to identify the underlying changes occurring in the U.S. economy. Therefore, students are provided with the quarterly data on U.S.

\footnotetext{
${ }^{1}$ Using Data in the Undergraduate Science Classroom was on an interdisciplinary workshop held at Carleton College, April 2002. The workshop was sponsored by the National Science Digital Library with funding from the National Science Foundation, Division of Undergraduate Education.
} 
real GDP from 2008 to 2011 from the website of Bureau of Economic Analysis. ${ }^{2}$ The data offer two approaches for teaching GDP and its components. First, students are asked to observe the trends in real GDP. U.S. real GDP decreased for two consecutive quarters in the third and fourth quarters of 2008, indicating that the U.S. economy was in a recession at the end of 2008. This decline in real GDP continued through the first and second quarters of 2009. Real GDP rebounded in the third quarter of 2009, and the economic growth rate has been positive ever since. By examining the patterns of real GDP quarter by quarter, students gain a better understanding of the business cycles in the U.S. economy. Second, students are invited to make observations of the trends in each component of real GDP. As the data show, personal consumption and aggregate investment declined from the second quarter of 2008 to the second quarter of 2009, while the trade balance saw fewer deficits during the same time period. Meanwhile, government expenditures increased during the period of 2008-2010 due to the economic stimulus plan. This comparison of various GDP components enables students to observe the dynamics between GDP and its components, as well as the role of government in the national economy. To implement the above activities, an exercise consisting of economic data and questions about such data is distributed in class. Students are divided into groups to complete the questions and discuss them with their peers within the allotted time (about 10 minutes). When the practice time is over, students volunteer to answer the questions at issue or supplement the answers of other groups.

Once students understand the various components of domestic GDP, they apply this knowledge to international data. To facilitate this extension of their learning, students are again divided into groups. Using GDP data on other countries, students compare the trends in other economies to those in the U.S. economy and present the resultant findings in class. This in-class exercise demonstrates the interconnectedness of world economies and explains why the U.S. recession in 2008-2009 spread to other countries. Allowing students to explore and analyze other countries' data reinforces the set of concepts pertaining to GDP, enhances students' data analytical skills, and stimulates students to think independently and critically. By integrating statistical data into the classroom, the dull presentation of GDP and static pictures of the national economy are turned into dynamic, vivid depictions reflecting various facets of the economy.

\section{Case 2: Federal Government Deficit and Debt}

The unprecedented increase in federal debt has become a concern to the policy maker and U.S. public alike. Thus, it is critical that students in macroeconomic principles courses appreciate the implication of this burgeoning problem to the health of the U.S. economy. The textbook, Principles of Macroeconomics by Case, Fair and Oster (2010) provides data on federal government receipts and expenditures in 2009 and charts the ratio of federal government debt to GDP for the Clinton, Bush, and Obama Administrations. Yet, the textbook's data on the size of the federal debt are outdated, provide no information about the distribution of holders of government debt, and fail to provide other more meaningful comparisons. Therefore, supplemental information on this issue is necessary in order to enrich the content. Consequently, data on the latest national debt from the website, National Debt Clock, as well as the U.S. population are compiled in order to allow students to compute the average debt burden per capita. As of April 29, 2011, the debt per citizen was $\$ 46,053$ and the debt per tax-payer was $\$ 128,823$. Comparing the size of the national debt per capita to median U.S. household income ( $\$ 50,221$ in 2010) deepens the students' comprehension of the severity of the national debt crisis. ${ }^{3}$ Furthermore, U.S. Treasury Department data concerning the major foreign holders of U.S. treasury securities are utilized to inform students about the international distribution of the national debt. It is also important for students to understand that this debt crisis is not confined to the U.S. Especially for relatively smaller European economies, the debt crisis imposes even greater threats to their national economic futures. Data from public media show that the private and public sectors of five fiscally shaky European countries, including Greece, Ireland, Portugal, Spain, and Italy, not only owe each other billions of Euros, but also have amassed even larger debts to Britain, France, and Germany. This mountain of debt has even called into question the future viability of the European Union financial systems. ${ }^{4}$

\footnotetext{
${ }^{2}$ Nominal GDP is GDP valued at the current prices, while real GDP is nominal GDP adjusted for price changes (Case, Fair \& Oster, 2010).

${ }^{3}$ The median household income is from the U.S. News, "Median U.S. Household Income by State", by U.S. News staff, October $5,2010$.

${ }^{4}$ Data are from the New York Times.
} 
To reinforce the proposition that the world truly is a global economy, it is pointed out in class that the synergies of this European financial crisis have wreathed havoc on the U.S. financial markets, as well as those in Asia. To underscore this point, students are once again divided in groups and assigned to collect various countries' data concerning the percentage of federal debt to national GDP and the interest rates on the government securities that underlie the national debt. Furthermore, students are asked to examine major economic variables, such as GDP growth rate, GDP per capita, inflation rates, and unemployment rates and to think about the implications of debt for a country's economy. In the next class, each group presents its findings on these matters. After the presentation, students are mingled to discuss in more detail the implications of rising debt worldwide to the U.S. government.

By supplementing textbook figures with current statistical information and by directing hands-on practices and peer-to-peer discussion, the pedagogical practice is able to raise students' awareness of the potential consequences of national debt, as well as the critical role debt plays to the future of the entire global economy.

\section{CONCLUSION}

Given the importance of economic data in understanding macroeconomics and the literature on the interactive lectures and learning outcome improvement for science classes, the pedagogical technique of teaching with data is incorporated in the principles of macroeconomics course. Two class activities involving collecting and interpreting data are discussed in this study. Such activities allow me to engage all students in the learning process, to promote student retention of more of the material presented during the lectures, and to give students practice in developing critical-thinking skills. Future research might include comparing standard test scores for classes taught with and without data-enhanced experience or surveying class taught with data-enhanced experience to examine the effectiveness of this teaching technique in economic education.

\section{AUTHOR INFORMATION}

Hong Zhuang is an Assistant Professor of Economics at Indiana University South Bend. Dr. Zhuang received her $\mathrm{PhD}$ from University of Oregon, Oregon, U.S.A. Her specialized field is international economics and economic growth. E-mail: zhuangh@iusb.edu

\section{REFERENCES}

1. Case, K. E., Fair, R. C., \& Oster, S. M. (2010). Principles of Macroeconomics. Upper Saddle River, New Jersey:Prentice Hall.

2. Kennedy, P. E. (2006). The Macroeconomics Principles Course: What Should Be Done? In Becker, William E., Watts, Michael, and Becker, Suzanne R. (Ed.), Teaching Economics: More Alternatives to Chalk and Talk (89-107). Cheltenham: Edward Elgar Publishing.

3. Boskin, M. J. (1988). Observations on the Use of Textbooks in the Teaching of Principles of Economics. The Journal of Economics Education, 19, 157-164.

4. Wenzel, T. J. (1999). The Lecture as a Learning Device. Analytical Chemistry, 71, 817A-819A.

5. Hake, R. R. (1998) Interactive-Engagement versus Traditional Methods: A Six-Thousand-Student Survey of Mechanics Test data for Introductory Physics Courses. The American Journal of Physics, 66, 64-74.

6. Manduca, C. A. \& Mogk, D. W. (2002). Using Data in Undergraduate Science Classroom. Retrieved May 3, 2011 from http://serc.carleton.edu/files/usingdata/UsingData.pdf. 